\title{
Evaluation Conclusion Code
}

National Cancer Institute

\section{Source}

National Cancer Institute. Evaluation Conclusion Code. NCI Thesaurus. Code C93564.

A coded value specifying the findings from the assessment. 